J. Clin. Chem. Clin. Biochem.

Vol. 27, 1989, pp. 351-359

(C) 1989 Walter de Gruyter \& Co. Berlin · New York

\title{
Enzyme Linked Immunosorbent Assays (ELISA) for the Quantitative Determination of Human Leukocyte Collagenase and Gelatinase
}

\author{
By U. Bergmann, J. Michaelis, Renate Oberhoff, Vera Knäuper, R. Beckmann and H. Tschesche
}

Fakultät für Chemie, Lehrstuhl Biochemie, Universität Bielefeld

(Received March 31, 1988/February 21, 1989)

Summary: A competitive and a sandwich enzyme linked immunosorbent assay (ELISA) were developed for human leukocyte collagenase and gelatinase.

The competitive assay could detect $0.5 \mathrm{ng}$ collagenase and $0.05 \mathrm{ng}$ gelatinase. The detection limit of the sandwich ELISA was $0.05 \mathrm{ng}$ for collagenase and $0.02 \mathrm{ng}$ for gelatinase.

No cross reactivity between human leukocyte collagenase and gelatinase was detected. The sandwich ELISA was used to determine plasma levels of these enzymes. The $90 \%$ range for collagenase was between 0 and $50 \mu \mathrm{g} / \mathrm{l}$; the $90 \%$ range for gelatinase was between 27 and $94 \mu \mathrm{g} / \mathrm{l}$.

\section{Introduction}

Inflammatory processes are associated with the release of proteolytic enzymes from phagocytic leukocytes (1).

In addition to the serine proteinases, cathepsin $\mathrm{G}$ and elastase, leukocytes have been shown to contain the metalloenzymes collagenase $\left.{ }^{1}\right)$ and gelatinase $\left.{ }^{1}\right)(2-4)$. All these proteases are able to degrade connective tissue components and thus might be involved in pathological conditions such as rheumathoid arthritis, tumour invasion, gout, or emphysema (5).

Although elastase is able to degrade collagen $(6,7)$, collagenase and gelatinase are the specific enzymes that are mainly responsible for the collagen breakdown mediated by leukocytes $(8,9)$.

1) alkaline phosphatase

collagenase gelatinase

horseradish peroxidase
- orthophosphoric-monoester phosphohydrolase (alkaline optimum)

EC 3.1.3.1

- EC 3.4.24.7

- EC 3.4.24. -

- donor: hydrogen-peroxide oxidoreductase EC 1.11.1.7
In order to study the release and function of these enzymes in body fluids and tissues, a highly sensitive and specific assay procedure is a prerequisite.

Collagenase and gelatinase concentrations are commonly determined by measuring their proteolytic activity against natural or synthetic substrates (for a review see 1.c. $(10,11))$. The assay of substrate degradation is achieved by using radioactive, fluorescent (12) or chromophore labelled substrates, as well as by measuring the change in physical parameters such as viscosity or UV-absorbance (13).

Substrate degradation was also detected by reacting the cleavage products with fluorescamine, which allows the assay of the amino groups generated during proteolytic action $(14,15)$.

Another kind of assay, which is preferentially used for qualitative determinations, involves analysing the degradation products by SDS-polyacrylamide gel electrophoresis (SDS-PAGE) (4).

Recently a collagenase assay has been described, which uses the highly sensitive ELISA technique for the detection of collagen degradation (16). By this assay the substrate, but not the protease itself, is 
detected by ELISA. Collagen is thereby bound to the solid phase and incubated with the sample. The cleaved collagen is washed out and the residual collagen determined by an indirect ELISA using anti type I collagen antibodies.

But all these methods share the common drawback that specific determinations are difficult or impossible, because all the substrates can be cleaved by more than one enzyme. The specific determination of proteases in samples containing complex mixtures of proteins, for example body fluids or cell culture supernatants, could be achieved by use of immunoassays. Specific inmunosassays have been reported so far only for collagenase synthesized by fibroblasts. Bauer et al. (17) report a RIA, while Cooper et al. (18) describe a competitive ELISA, but neither assay allows the determination of the leukocyte enzyme.

In this paper we wish to report ELISA methods for determining collagenase and gelatinase of the human leukocyte.

\section{Materials and Methods}

\section{Materials}

Microelisa and Nunc Immuno plate II, flat bottom microtitration plates, were obtained from Dynatech (Denkendorf, FRG) and Nunc (Roskilde, Denmark), respectively. Horseradish peroxidase $^{1}$ ) (ELISA grade) was obtained from Boehringer Mannheim (Mannheim, FRG). Anti rabbit IgG, prepared in goats, conjugated to horseradish peroxidase was purchased from Nordic (Biogenzia Lemania, Bochum, FRG). The alkaline phosphatase conjugated form of this antibody and 2,2'-azinobis(3-ethylbenzthiazolinesulphonic acid) (ABTS) were from Sigma (Deisenhofen, FRG). $\alpha_{2}$-Macroglobulin was obtained from Behring Werke (Marburg, FRG); the inhibitor activity was proved by saturating the $\alpha_{2}$-macroglobulin with trypsin, inhibiting all free trypsin, and quantifying the bound trypsin by using benzoyl-arginine nitroanilide as the substrate (19).

The absorbance of the solutions in the microtitration plates was measured by a Dynatech Microelisa-Autoreader MR 580.

Immobilon PVDF blotting membrane was purchased from Millipore (Eschborn, FRG). Blood samples were supplied by Dr. Kleesiek, Herzzentrum Nordrhein-Westfalen, FRG).

Preparation of leukocyte collagenase and gelatinase standards

Latent human polymorphonuclear leukocyte collagenase and gelatinase were prepared from buffy coat as described elsewhere $(2,4,20)$. The active enzymes were prepared by activating the latent enzymes with either trypsin or mercurial compounds (4, 20 ). The collagenase activity was demonstrated by specific cleavage of type I collagen into the characteristic $3 / 4$ and $1 / 4$ fragments. The gelatinase activity was proved by degrading denatured type I collagen (gelatin).

The protein content of the collagenase and gelatinase standard solutions was determined by using amino acid analysis as described in more detail elsewhere (4).

\section{Preparation of antibodics}

Rabbits were immunized with $400 \mu \mathrm{g}$ of the purified latent enzymes in complete Freund's adjuvant by subcutaneous injection. Two further booster immunizations were carried out with the same amount of antigen in incomplete Freund's adjuvant.

The IgG fraction was prepared from the antisera by precipitation with ammonium sulphate and anion exchange chromatography on DEAE-Sepharose according to 1.c. (21). The purified antibodies were analysed by using the double immunodiffusion technique (22).

\section{Western blot analysis}

Protein samples were separated by SDS-PAGE and blotted onto a PVDF membrane using the Biometra Fast Blot System. The blotting membrane was incubated with specific antisera. Bound antibody was identified by incubating with goat anti rabbit IgG-alkaline phosphatase conjugate and reacting with nitro blue tetrazolium/5-bromo-4-chloro-3-indolyl phosphate as an alkaline phosphatase substrate. The details of the immunoblot procedure are described elsewhere (4).

\section{Conjugation of horseradish peroxidase to specific} IgG

Specific IgG was reacted with horseradish peroxidase by a modification of the method described by Tijssen \& Kurstak (23). Horseradish peroxidase $(1.7 \mathrm{mg})$ was dissolved in $170 \mu \mathrm{l}$ $0.1 \mathrm{~mol} / 1$ sodium carbonate buffer, $\mathrm{pH} 8.3$, and incubated with $170 \mu \mathrm{l}$ of the same buffer containing $8 \mathrm{mmol} / 1 \mathrm{NaIO}_{4}$ for 15 $\mathrm{min}$, at $25^{\circ} \mathrm{C}$, in the dark. Then $5 \mathrm{mg} \mathrm{IgG}$ in $400 \mu \mathrm{l} 0.1 \mathrm{~mol} / 1$ sodium carbonate buffer, pH 9.2, were added, followed by the addition of $0.13 \mathrm{~g}$ Sephadex G-25 $\mathrm{f}$. After an incubation time of $3 \mathrm{~h}$ the Sephadex was centrifuged (Eppendorf centrifuge, 10 min full speed). The pellet was washed with $200 \mu \mathrm{l}$ of the carbonate buffer and centrifuged again; this washing procedure was repeated. The combined supernatants were reacted with 40 $\mu l 0.1 \mathrm{~mol} / \mathrm{l} \mathrm{NaOH}$ containing $\mathrm{NaBH}_{4}$ at a concentration of $5 \mathrm{~g} / \mathrm{l}$. The same solution was added for a second time after 30 min. The admixture was cooled down to $4{ }^{\circ} \mathrm{C}$ and after an incubation time of $1 \mathrm{~h}$ the conjugate was sedimented by addition of an equal volume of saturated $\left(\mathrm{NH}_{4}\right)_{2} \mathrm{SO}_{4}$ solution. After at least $1 \mathrm{~h}$, the precipitate was centrifuged and the supernatant was discarded. The pellet was washed with half saturated $\left(\mathrm{NH}_{4}\right)_{2} \mathrm{SO}_{4}$ solution and transferred to $0.2 \mathrm{~mol} / \mathrm{l}$ sodium phosphate $\mathrm{pH} 7.4,0.15 \mathrm{~mol} / \mathrm{l} \mathrm{NaCl}$. The conjugate could be stored in liquid solution at $-20^{\circ} \mathrm{C}$ after addition of an equal amount of glycerol; it was used in the sandwich ELISA without further purification.

\section{ELISA procedure}

\section{Competitive assay}

The antigens used for solid phase coating were dissolved in coating buffer $(50 \mathrm{mmol} / \mathrm{l}$ sodium carbonate $\mathrm{pH} 9.6,0.2 \mathrm{~g} / \mathrm{l}$ sodium azide) at $0.2 \mathrm{mg} / \mathrm{l}$ and incubated with the microtitration plate $(200 \mu \mathrm{l} /$ well $)$ for about $12 \mathrm{~h}$ at $4^{\circ} \mathrm{C}$. An excess of antigen was removed by washing with $0.2 \mathrm{~mol} / 1$ sodium phosphate, $\mathrm{pH}$ $7.4,0.15 \mathrm{~mol} / 1 \mathrm{NaCl}, 0.5 \mathrm{~g} / 1$ Tween 20 twice. The standards (stock solution of $20-200 \mathrm{mg} / \mathrm{l}$ ) were diluted to a final concentration not exceeding $2 \mathrm{mg} / \mathrm{l}$ in phosphate buffered saline/ Tween containing $20 \mathrm{~g} / \mathrm{l}$ bovine serum albumin. The specific IgG was added to give a final concentration of $30 \mu \mathrm{g} / 1$ for the gelatinase determination and $15 \mu \mathrm{g} / 1$ for the collagenase determination. The sample dilution has to be elucidated for each kind of material. Appropriate dilution factors range from 2 to 10000. The diluted antigen-antibody admixtures were pre-incubated for at least $3 \mathrm{~h}$ at $25^{\circ} \mathrm{C}$ and added to the microtitration 
plate. After an incubation time of $3 \mathrm{~h}$ at $25^{\circ} \mathrm{C}$ the plate was washed 4 times with phosphate buffered saline/Tween and incubated at the same temperature for $2 \mathrm{~h}$ with goat anti rabbit IgG horseradish peroxidase conjugate (diluted $1: 1750$ in phosphate buffered saline/Tween/bovine serum albumin).

The plate was washed 6 times in phosphate buffered saline/ Tween and the substrate reaction was carried out by incubating at $18^{\circ} \mathrm{C}$ for $2 \mathrm{~h}$ with $2,2^{\prime}$-azino-bis (3-ethylbenzthiazolinesulphonic acid) (ABTS), adjusted to $0.5 \mathrm{~g} / 1$ in citrate buffer $(0.1$ mol/l citric acid, adjusted to $\mathrm{pH} 4.2$ with $\mathrm{Na}_{2} \mathrm{HPO}_{4}, 0.5 \mathrm{~g} / \mathrm{l}$ Tween $20,1.3 \mathrm{mmol} / 1 \mathrm{H}_{2} \mathrm{O}_{2}$ ). Absorbance was measured at $405 \mathrm{~nm}$.

\section{Sandwich ELISA}

Microtitration plates were coated with $200 \mu$ l specific antibody at a concentration of $2 \mathrm{mg} / 1$ in coating buffer overnight at $4{ }^{\circ} \mathrm{C}$. After 2 washing cycles with phosphate buffered saline/Tween the samples, diluted in phosphate buffered salinc/Tween/bovinc serum albumin, were added and incubated for $3 \mathrm{~h}$ at room temperature. The standards and samples were diluted to within the same range as given for the competitive assay. After the plate had been washed 4 times with phosphate buffered saline/ Tween the horseradish peroxidase conjugated specific antibody $(1: 3000$ in phosphate buffered saline/Tween/bovine serum albumin) was added for $2 \mathrm{~h}$ at room temperature. The following procedure was the same as given for the indirect assay.

\section{Blood samples}

Blood samples from healthy donors $(20-30$ years old, $70 \%$ male) were collected in EDTA coated tubes and centrifuged within $3 \mathrm{~h}$ at $2000 \mathrm{~g}$ for $10 \mathrm{~min}$ (during this period no leakage was observed). The plasma samples used for the determinations of normal ranges were stored for no longer than $20 \mathrm{~h}$ at $4^{\circ} \mathrm{C}$ before analysis by the ELISA methods described above. In the collagenase assay, the samples were serially diluted in four steps, starting with twofold diluted plasma. Appropriate dilution factors for the gelatinase assay ranged from 4 to 32 .

In cases where samples without EDTA were required, plasma was prepared from heparin blood.

\section{Results}

\section{Specificity of antibodies}

The specificity of the antisera was proved by Western blot analysis. The detection of collagenase or gelatinase in crude leukocyte extracts using Western blotting was impossible, because of the very high amount of contaminating protein which is present in this material.

Thus, a partially purified leukocyte extract was used to determine the antigens in Western blots. The bands observed (fig. 1) were the same as those of the purified enzymes. The. fact that more than one band is observed in the case of collagenase is due to the autolysis of this enzyme (for details see l.c. (4)).

Furthermore, collagenase and gelatinase were assayed during the purification of the enzymes $(4,20)$ both by determining the enzymatic activities and by using

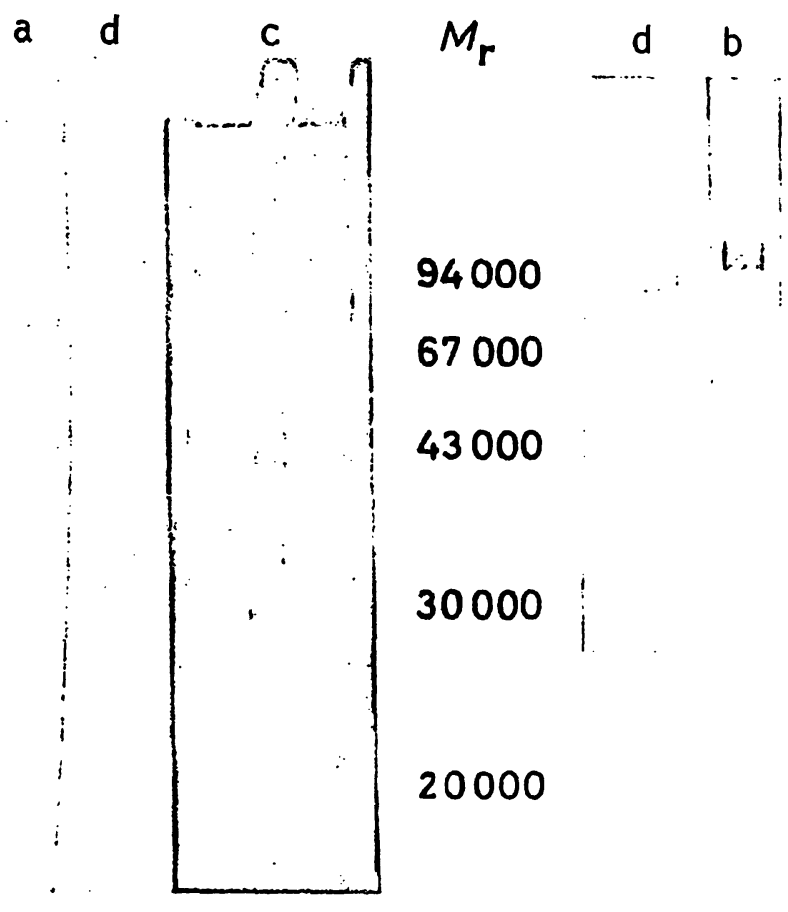

Fig. 1. Western blot analysis of anti collagenase (a) and anti gelatinase (b) antibodies.

The partially purified leukocyte enzymes were separated on a $7.5 \%$ polyacrylamide gel, transferred to the immobilon blotting membrane and incubated with specific antibody followed by alkaline phosphatase antibody conjugate and substrate (nitro blue tetrazolium/5bromo-4-chloro-3-indolyl phosphate). The corresponding polyacrylamide gels are shown in (c). The transferred marker proteins (d) were stained using Coomassie blue.

the sandwich ELISA. The enzymatic activity of the isolated samples corresponded with the immunological activity for each enzyme.

When the double immunodiffusion was used to prove the specificity, both antibodies showed no interaction with human albumin, lactoferrin, fibronectin and laminin. There was likewise no cross reactivity between collagenase and gelatinase antibody, and no cross reactivity between gelatinase and collagenase antibody (fig. 2).

Collagenase and gelatinase could be detected in their latent form and after activation by either mercury compounds or proteases.

Neither collagenase $(2 \mathrm{~g} / \mathrm{l})$ nor gelatinase $(2 \mathrm{~g} / \mathrm{l})$ showed any cross reactivity with the gelatinase or collagenase sandwich ELISA, respectively. Thus, the cross reactivity was below $0.1 \%$, with respect to the detection limits. 
1

6

2

7

5 3

4

Fig. 2. Double immunodiffusion technique using the specific anti collagenase antibody.

Well 1: purified latent collagenase; well 2: purified latent gelatinase; well 3: human lactoferrin; well 4: human serum albumin; well 5: human plasma fibronectin; well 6: human laminin; antigen concentrations $0.4 \mathrm{~g} / \mathrm{l}$. centre well: anti collagenase antibody $2 \mathrm{~g} / \mathrm{l}$.

A similar result (not shown) was obtained by using anti gelatinase antibody (well 7) and purified gelatinase (well 2) in the same experiment.

\section{Tuning of ELISA reaction parameters}

\section{Substrate reaction}

An appropriate $\mathrm{H}_{2} \mathrm{O}_{2}$-concentration, and $\mathrm{pH}$ for the substrate conversion was determined using chess board titration. The substrate solutions were adjusted to a $\mathrm{pH}$ between 3.5 and 4.8 ; the $\mathrm{H}_{2} \mathrm{O}_{2}$ concentrations ranged from 0 to $6.2 \mathrm{mmol} / \mathrm{l}$. Maximum absorbance for $2 \mathrm{~h}$ reaction time was achieved at $\mathrm{pH} 4.2$ and 1.3 $\mathrm{mmol} / 1 \mathrm{H}_{2} \mathrm{O}_{2}$; an ABTS concentration of $0.5 \mathrm{~g} / 1$ was sufficient. The reaction was carried out at $18^{\circ} \mathrm{C}$, taking into account detailed studies reported on elsewhere (24).

The effect of conjugate concentrations were determined by using chess board titration with the enzyme linked antibodies diluted stepwise from $1: 800$ to $1: 500,000$. The most suitable dilutions are given in materials and methods. A further increased conjugate concentration resulted mainly in higher background reaction but only in slightly improved sensitivity. The effect of the amount of the solid phase protein was studied in a similar experiment. Complete saturation of the solid phase was achieved at protein concentrations above $1 \mathrm{mg} / \mathrm{l}$. Nevertheless, if only limited amounts of protein were available, the concentration used for solid phase coating could be reduced to 0.2 $\mathrm{mg} / \mathrm{l}$ without a serious loss of sensitivity.

The amount of specific antibody which is added to the solid phase, is crucial to sensitivity in the competitive assay. The optimal concentrations are given in Materials and Methods. They were selected according to experiments in which the antibody was adjusted to concentrations ranging from $200 \mu \mathrm{g} / 1$ to $1.5 \mathrm{~g} / 1$.

\section{Sensitivity and precision}

Standard curves (figs. 3 and 4 ) for the determination of human leukocyte collagenase and gelatinase were established using the optimized reaction parameters given above. The standard curves were not changed when the enzymes were activated by either mercury compounds or proteases.

The within-assay precision of the four assays is given in the tables 1 and 2 . The competitive and the sandwich assay have comparable response errors. The competitive assay is, however, less precise, due to the smaller slope of its standard curve.

The detection limits, obtained by setting the negative cut off value at three standard deviations of the negative control, are given in tables 1 and 2 . A collagenase and gelatinase quantification with sufficient precision (CV below 10\%) can be achieved at concentrations as low as $0.5-1 \mu \mathrm{g} / 1$ when the sandwich assay is used. The competitive ELISA is about ten times less sensitive.

Therefore, only the sandwich assays were used in the further investigations.

Their between-assay precision is given in tables 1 and 2.

Determination of collagenase and gelatinase concentrations in plasma

When serially diluted plasma samples were analysed by the sandwich ELISA, the dose response curves were of the same shape as the standard curves. Collagenase and gelatinase samples, however, were not fully recovered in heparin plasma when $\alpha_{2}$-macroglobulin and the proteases were active. A similar effect was observed after reacting the active enzymes with purified $\alpha_{2}$-macroglobulin. 


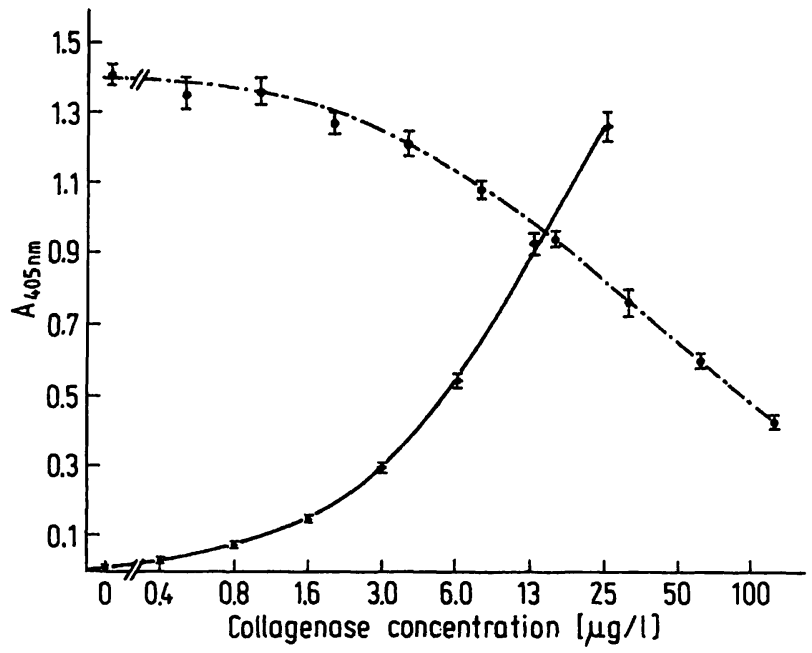

Fig. 3. Standard curves for the assays of collagenase.

Under the optimized assay conditions, standard curves were determined. Standard deviations were calculated as described in table 1.

sandwich assay:

competitive assay: $\bullet \cdot-\cdot \cdot \cdot-\bullet$

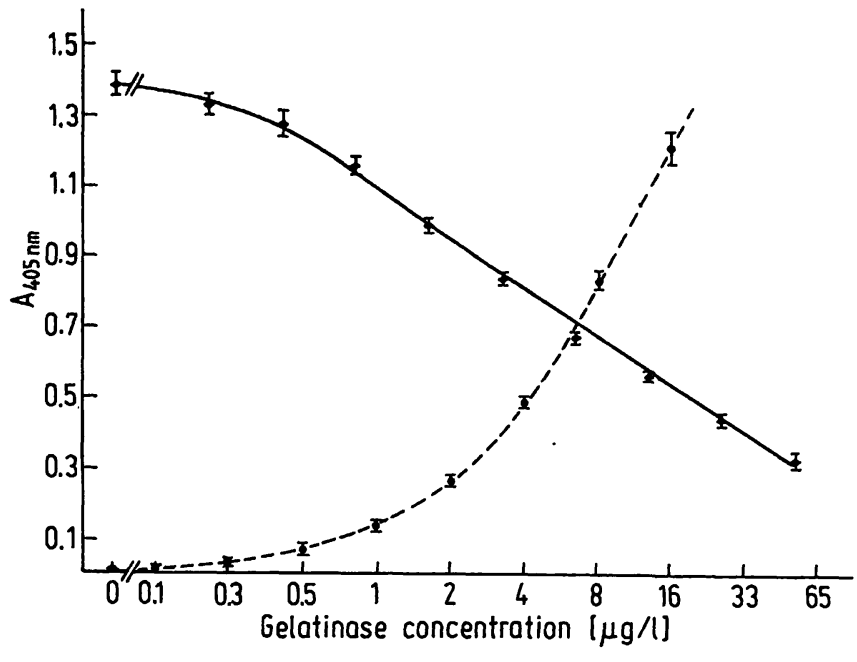

Fig. 4. Standard curves for the assays of gelatinase. Under the optimized assay conditions, standard curves were determined. Standard deviations were calculated as described in table 2 .

sandwich assay: $\bullet---\infty$

competitive assay: $0-0$

Tab. 1. Imprecision of the collagenase sandwich and competitive ELISA; in order to determine the precision profile, concentrations were determined from the absorbance values using the standard curve (fig. 3 ). These concentration values were used to calculate the standard deviations (SD) and the coefficients of variation (CV). Detection limits are added.

\begin{tabular}{|c|c|c|c|c|c|c|c|c|c|c|}
\hline Concentration & Response & \multicolumn{2}{|c|}{ Response error } & \multicolumn{2}{|c|}{ Precision profile } & Response & \multicolumn{2}{|c|}{ Response error } & \multicolumn{2}{|c|}{ Precision profile } \\
\hline$(\mu \mathrm{g} / \mathrm{l})$ & $\mathrm{A}_{405 \mathrm{~nm}}$ & $\begin{array}{l}\text { SD } \\
A_{405 \mathrm{~nm}}\end{array}$ & $\begin{array}{l}\text { CV } \\
(\%)\end{array}$ & $\begin{array}{l}\mathrm{SD} \\
(\mu \mathrm{g} / \mathrm{l})\end{array}$ & $\begin{array}{l}\mathrm{CV} \\
(\%)\end{array}$ & $\mathrm{A}_{405 \mathrm{~nm}}$ & $\begin{array}{l}\mathrm{SD} \\
\mathrm{A}_{405 \mathrm{~nm}}\end{array}$ & $\begin{array}{l}\mathrm{CV} \\
(\%)\end{array}$ & $\begin{array}{l}\mathrm{SD} \\
(\mu \mathrm{g} / \mathrm{l})\end{array}$ & $\begin{array}{l}\text { CV } \\
(\%)\end{array}$ \\
\hline
\end{tabular}

Collagenase sandwich ELISA

\begin{tabular}{|c|c|c|c|c|c|c|c|c|c|c|}
\hline \multirow[b]{2}{*}{25.0} & \multicolumn{5}{|c|}{ Intraa-assay imprecision $(n=8)$} & \multicolumn{5}{|c|}{ Inter-assay imprecision $(n=14)$} \\
\hline & 1.362 & 0.049 & 3.7 & 2.6 & 10 & & & & & \\
\hline 12.5 & 0.975 & 0.045 & 4.6 & 1.1 & 8 & 0.930 & 0.068 & 7.3 & 1.3 & 11 \\
\hline 6.3 & 0.574 & 0.023 & 4.0 & 0.3 & 5 & 0.547 & 0.051 & 9.3 & 0.6 & 10 \\
\hline 3.1 & 0.305 & 0.009 & 2.9 & 0.1 & 3 & 0.297 & 0.022 & 7.4 & 0.2 & 7 \\
\hline 1.6 & 0.164 & 0.009 & 5.5 & 0.1 & 6 & 0.152 & 0.021 & 14 & 0.20 & 13 \\
\hline 0.8 & 0.085 & 0.005 & 5.9 & 0.05 & 6 & 0.075 & 0.016 & 21 & 0.2 & 25 \\
\hline 0.4 & 0.043 & 0.009 & 21 & 0.1 & 25 & \multirow{2}{*}{\multicolumn{5}{|c|}{ Detection limit: $0.25 \mu \mathrm{g} / 1 \cong 0.05 \mathrm{ng}$ per assay }} \\
\hline control & 0 & 0.005 & & & & & & & & \\
\hline
\end{tabular}

\section{Collagenase competitive ELISA}

\begin{tabular}{|c|c|c|c|c|c|c|}
\hline \multirow[b]{2}{*}{500} & \multicolumn{6}{|c|}{ Intra-assay imprecision $(n=8)$} \\
\hline & 0.132 & 0.022 & 16. & 115 & 23 & $\therefore$ \\
\hline 250 & 0.268 & 0.030 & 11 & 45 & 18 & . \\
\hline 125 & 0.430 & 0.032 & 7.5 & 20 & 16 & . \\
\hline 63 & 0.601 & 0.049 & 8.2 & 8.8 & 14 & \\
\hline 31 & 0.763 & 0.045 & 6.1 & 4.7 & 15 & • \\
\hline 16 & 0.938 & 0.041 & 4.4 & 2.5 & 17 & \\
\hline 8 & 1.078 & 0.035 & 3.3 & 1.5 & 19 & \\
\hline 4 & 1.212 & 0.048 & 4.0 & 1.0 & 26 & \\
\hline 2 & 1.269 & 0.075 & 5.9 & 0.4 & 22 & \\
\hline 1 & 1.365 & 0.041 & 3.0 & 0.4 & 40 & \\
\hline control & 1.411 & 0.041 & 4.5 & & & Detection limit: $2.5 \mu \mathrm{g} / 1 \cong 0.5 \mathrm{ng}$ per assay \\
\hline
\end{tabular}


Tab. 2. Imprecision of the gelatinase sandwich and competitive ELISA; in order to determine the precision profile, concentrations were determined from the absorbance values using the standard curve (fig. 4). These concentration values were used to calculate the standard deviations (SD) and the coefficients of variation (CV). Detection limits are added.

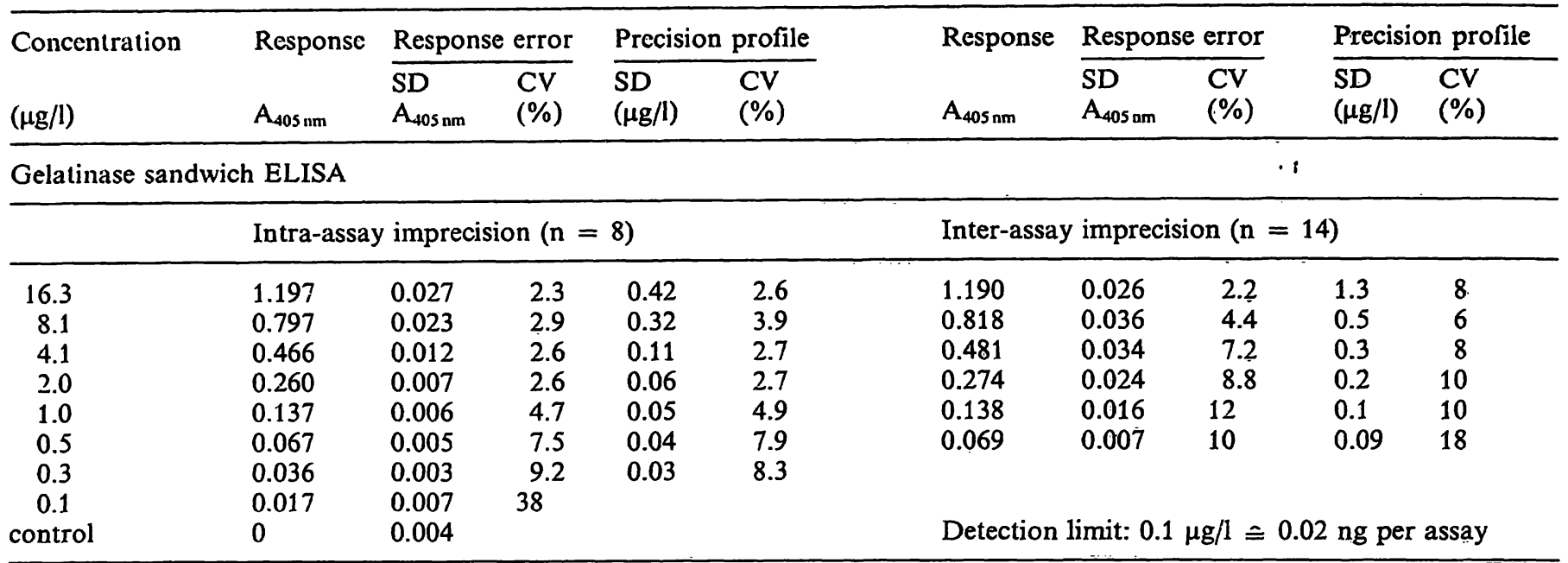

Gelatinase competitive ELISA

\begin{tabular}{|c|c|c|c|c|c|c|}
\hline \multirow[b]{2}{*}{104} & \multicolumn{5}{|c|}{ Intra-assay imprecision $(\mathrm{n}=8)$} & \\
\hline & 0.280 & 0.007 & 2.6 & 4.0 & 3.8 & \\
\hline 52 & $\therefore \quad 0.329$ & 0.026 & 8.7 & 12 & 23 & \\
\hline 26 & 0.436 & 0.017 & 3.9 & 2.9 & 11 & \\
\hline 13 & 0.564 & 0.013 & 2.3 & 0.83 & 6.4 & \\
\hline 6.5 & 0.675 & 0.016 & 2.3 & 0.51 & 7.9 & \\
\hline 3.3 & 0.839 & 0.019 & 2.3 & 0.39 & 12 & \\
\hline 1.6 & 0.991 & 0.025 & 2.5 & 0.21 & 13 & \\
\hline 0.8 & 1.158 & 0.025 & 2.2 & 0.10 & 13 & \\
\hline 0.4 & 1.281 & 0.041 & 3.2 & 0.09 . & 22 & \\
\hline 0.2 & 1.335 & 0.033 & 2.5 & & & \\
\hline control & 1.394 & 0.032 & & & & Detective limit: $0.25 \mu \mathrm{g} / 1 \cong 0.05 \mathrm{ng}$ per assay \\
\hline
\end{tabular}

When the plasma used for recovery experiments had lost its active $\alpha_{2}$-macroglobulin ( $\alpha_{2}$-macroglobulin was inactive in plasma samples which were stored longer than $48 \mathrm{~h}$ at $4^{\circ} \mathrm{C}$ ) the recovery was of the same magnitude as the assay imprecision. Recovery was also complete when the proteolytic activity of the antigen standards was inhibited by adding EDTA (tab. 3). In addition, plasma proteins were separated according to molecular weight by gel chromatography, using a Superose 12 column; the eluted protein fractions were analysed by the sandwich ELISA. Collagenase and gelatinase could be detected only in the fractions corresponding to the molecular weight of the purified latent enzymes, but not in those fractions which contained $\alpha_{2}$-macroglobulin. These results suggest that mainly the latent collagenase and gelatinase are determined in plasma, but not the activated enzymes, which are readily trapped by $\alpha_{2}$-macroglobulin.

In order to determine normal ranges for collagenase and gelatinase in plasma, EDTA plasma samples from healthy donors were analysed (tab. 4). The EDTA prevents the latent collagenase and gelatinase from activation by any activating reagent and thus stabilizes the content of the immunoreactive form of these proteases.
Tab. 3. Recovery of collagenase and gelatinase in EDTA plasma. The antigen standards, diluted in phosphate buffered saline/Tween/bovine serum albumin were added to the same volume of an EDTA plasma sample. This admixture was serial diluted in 12 steps and analysed by the sandwich ELISA. Means from those dilutions (3-5 values) which gave responses of $A_{405 \mathrm{~nm}}$ between 0.1 and 1.0 .

\begin{tabular}{lllll} 
Collagenase & & & & \\
\hline Plasma & $\begin{array}{l}\text { Antigen } \\
\text { standard } \\
(\mu \mathrm{g} / \mathrm{l})\end{array}$ & Expected & Found & Recovery \\
$(\mu \mathrm{g} / \mathrm{l})$ & $(\mu \mathrm{g} / \mathrm{l})$ & $(\mu \mathrm{g} / \mathrm{l})$ & $(\%)$ \\
\hline 6.8 & 37 & 43.8 & 44 & 100.5 \\
4.5 & 8.9 & 13.4 & 12 & 89.5 \\
4.5 & 4.7 & 9.2 & 9.2 & 100 \\
4.5 & 1.4 & 5.9 & 6.7 & 114 \\
4.5 & 0.5 & 5.0 & 5.9 & 118 \\
\hline
\end{tabular}

Gelatinase

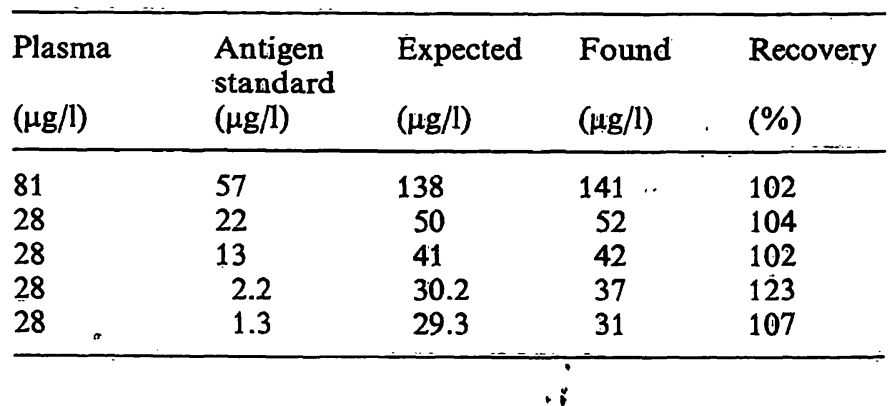


The distribution of concentrations is shown in figures 5 and 6 and in table 4 . The gelatinase concentrations are $\log$ normal distributed.

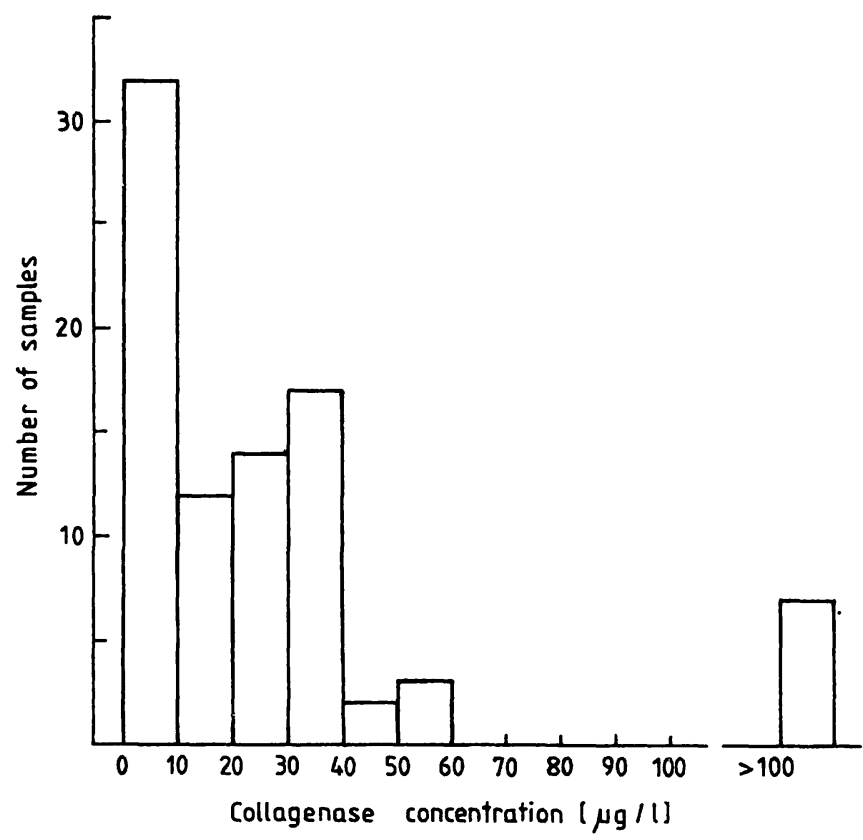

Fig. 5. Distribution of collagenase concentrations in human EDTA plasma from healthy donors $(n=100)$.
Collagenase and gelatinase determination in synovial fluid

Synovial fluid samples from patients with inflammatory $(n=24)$ and non-inflammatory $(n=28)$ rheumatoid arthritis were analysed. The collagenase and gelatinase concentrations were found to be much higher than in plasma. In addition the content of collagenase and gelatinase in samples from patients with inflammatory diseases were in most cases much higher than in non-inflammatory synovial fluids (tab. 4).

The overall protein content, however, did not show a corresponding fluctuation; the concentrations ranged from 30 to $55 \mathrm{~g} / \mathrm{l}$. Interestingly there was no correlation found in this preliminary investigation between the number of granulocytes or total leukocytes and the concentrations of collagenase and gelatinase determined by using the Spearman rank correlation analysis. These findings demonstrate the utility of the ELISA-procedure for investigations of physiological fluids.

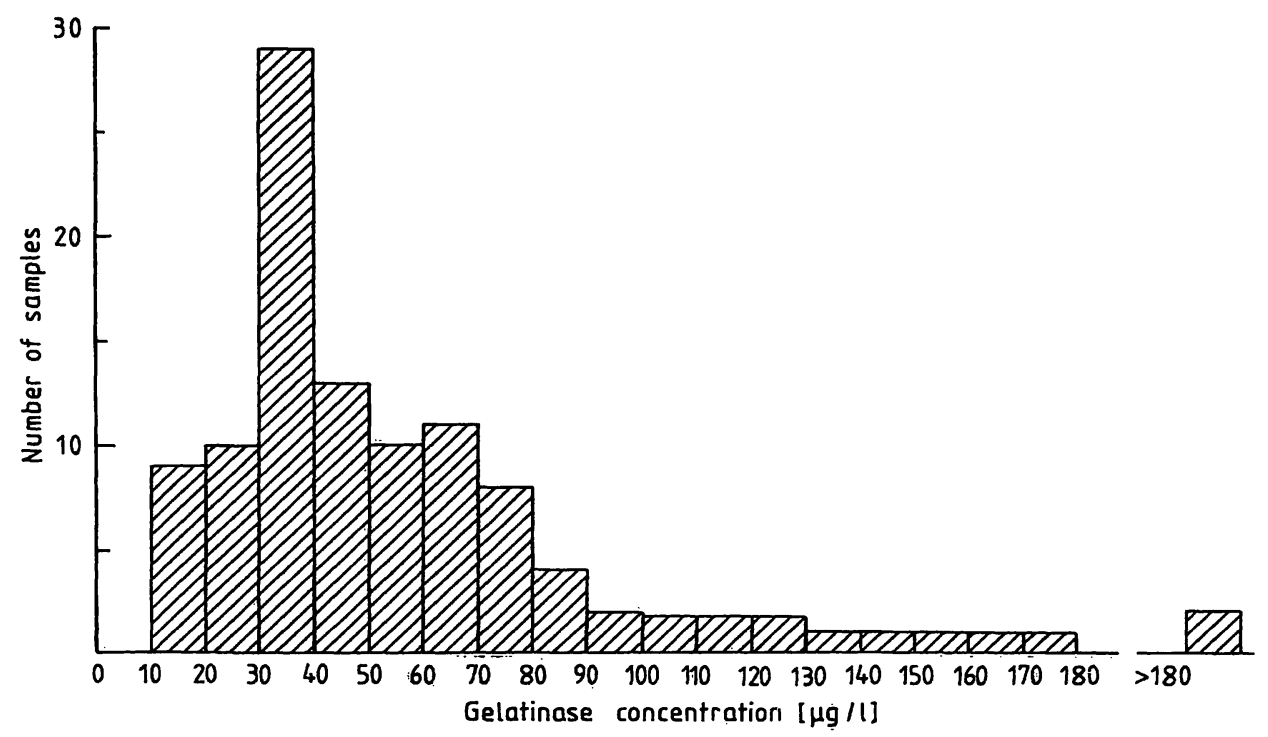

Fig. 6. Distribution of gelatinase concentrations in human EDTA plasma from healthy donors $(n=127)$.

Tab.4. Normal range for collagenase and gelatinase in EDTA plasma. Number of samples: collagenase $n=100$, gelatinase $\mathrm{n}=127$; the $90 \%$ range for collagenase was estimated from the distribution given in figure 5 , the gelatinase $90 \%$ range was calculated using the median and the scattering coefficient $(90 \%$ range $=$ median $\times$ scattering coefficient). The $90 \%$ ranges of collagenase and gelatinase in synovial fluids are also given.

\begin{tabular}{|c|c|c|c|c|c|}
\hline & \multirow{2}{*}{\multicolumn{3}{|c|}{ EDTA plasma }} & \multicolumn{2}{|l|}{ Synovial fluids } \\
\hline & & & & Non-inflammatory & Inflammatory \\
\hline & $\begin{array}{l}\text { Median } \\
(\mu \mathrm{g} / \mathrm{l})\end{array}$ & $\begin{array}{l}\text { Scattering } \\
\text { coefficient* }\end{array}$ & $\begin{array}{l}90 \% \text { range } \\
(\mu \mathrm{g} / \mathrm{l})\end{array}$ & $\begin{array}{l}90 \% \text { range } \\
(\mu \mathrm{g} / \mathrm{l})\end{array}$ & $\begin{array}{l}90 \% \text { range } \\
(\mu \mathrm{g} / \mathrm{l})\end{array}$ \\
\hline $\begin{array}{l}\text { Collagenase } \\
\text { Gelatinase }\end{array}$ & $\overline{51}$ & $\overline{1.85}$ & $\begin{array}{r}0-50 \\
27-94\end{array}$ & $\begin{array}{l}0-300 \\
0-800\end{array}$ & $\begin{array}{l}100-2500 \\
125-8000\end{array}$ \\
\hline
\end{tabular}

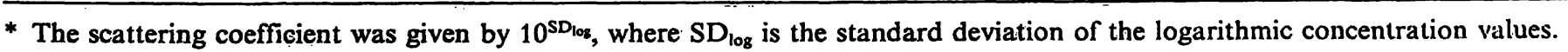




\section{Discussion}

Two enzyme linked immunosorbent assay procedures (ELISA) for the quantitative determination of human leukocyte collagenase and gelatinase were developed and evaluated. The antibodies used were able to detect latent and active collagenase, and latent and active gelatinase. Thus it was possible to quantify the total enzyme-protein. In plasma, however, one might suppose that mostly the latent enzymes are demonstrated. This is because the active enzymes can be inhibited by $\alpha_{2}$-macroglobulin. The $\alpha_{2}$-macroglobulin-protease complexes, moreover, do not respond. The sensitivity and precision achieved for the determination of leukocyte collagenase and gelatinase is comparable to that reported by Cooper et al. (18) for the determination of the fibroblast collagenase. The sandwich ELISA showed a lower detection limit and was more precise than the competitive assay. It also was easier to perform, because a preincubation of the sample with the specific antibody is not necessary. Furthermore, the indirect assay requires a rather large amount of antigen for solid phase coating. This is a disadvantage in the case of the leukocyte enzymes, because they have to be prepared from rather scarce preparations of valuable starting material and are available only in tiny amounts. For these reasons the sandwich ELISA is regarded to be superior to the competitive ELISA in routine analysis. The latter could, in some cases, be a useful additional test procedure for the exclusion of false positive and false negative results.

Most of the information available on vertebrate collagenase is derived from studies of the fibroblast en- zyme, which has been sequenced and cloned $(25,26)$. In contrast, little is known about the leukocyte enzymes. The amino acid sequences are unknown, the molecular weights estimated by various authors differ, and for the activation of the latent human leukocyte collagenase at least three different mechanisms have been assumed (review) l.c. (3)).

The ELISA procedures detailed in this paper could be generally helpful in further investigating collagen degradation mediated by leukocytes. The enzyme immuno assays are more sensitive than all proteolytic assays hitherto. Due to their high specifity, they can be used to analyse samples which contain a high amount of contaminating protein. The procedures, therefore, can be applied to determine the presence of leukocyte proteases in normal and pathological body fluids and connective tissue matrix. Such studies are in progress and they will be the subject of a separate paper. It is hoped to elucidate the significance of these enzymes in pathological processes.

\section{Acknowledgement}

The authors gratefully acknowledge the skillful technical assistance of Mrs. $V$. Süwer and Mrs. E. Krimpenfort in the purification of antibodies and in routine ELISA measurements. We are indebted to Mrs. C. Wiegand and Prof. Dr. B. $M$. Jockusch, Faculty of Biology, University of Bielefeld, for raising the antisera in rabbits.

The work was supported by the Deutsche Forschungsgemeinschaft, Bonn, SFB 223-Bielefeld and the Fond der Chemischen Industrie, Frankfurt.

\section{References}

1. Weissmann, G. (ed.) (1980) Handbook of inflammation Vol. 2. The cell biology of inflammation. Elsevier, Amsterdam.

2. Engelbrecht, S., Pieper, E., Macartney, H. W., Rautenberg, W., Wenzel, H. R. \& Tschesche, H. (1982) Hoppe-Seylers Z. Physiol. Chem. 363, 305-315.

3. Weiss, S. J. \& Peppin, G. J. (1986) Biochem. Pharmacol. 35, 3189-3197.

4. Michaelis, J. (1988) PhD Thesis, Universität Bielefeld: Michaelis, J., Bergmann, U. \& Tschesche, H.: in preparation.

5. Woolley, D. E. \& Evanson, J. M. (eds.) (1980) Collagenase in normal and pathological connective tissues. John Wiley \& Sons, Chichester.

6. Kobayashi, S. \& Nagai, Y. (1978) J. Biochem. 84, 559567.

7. Pipoly, D. J. \& Crouch, E. C. (1987) Biochemistry 26, 5748-5754.

8. Hibbs, M. S., Hasty, K. A., Seyer, J. M., Kang, A. H. \& Mainardi, C. M. (1985) J. Biol. Chem. 260, 2493-2500.

9. Hasty, K. A., Jeffrey, J. J., Hibbs, M. S. \& Welgus, H. G. (1987) J. Biol. Chem. 262, 10048-10052.

10. Harris, Jr., E. D. \& Vater, C. A. (1982) In: Methods in Enzymology, Vol. 82, Part A. (Cunningham, L. W. \& Frederiksen, D. W., eds.) pp. 423-439, Academic Press, New York.

11. Peterkofsky, B. (1982) In: Methods in Enzymology, Vol. 82, Part A. (Cunningham, L. W. \& Frederiksen, D. W., eds.) pp. 453-461, Academic Press, New York, 1982, pp. 453-461.

12. O'Grady, R. L., Nethery, A. \& Hunter, N. (1984) Anal. Biochem. 140, 490-494.

13. Lindy, S., Sorsa, T., Soumalainen, K., Lauhio, A. \& Turto, H. (1986) Eur. J. Biochem. 156, 1-4.

14. Tschesche, H. \& Macartney, H. W. (1984) In: Methods of enzymatic analysis, Vol. V, 3rd edn. (Bergmeyer, H. U., ed.) pp. 239-248, Verlag Chemie, Weinheim.

15. Tschesche, H., Macartney, H. W. \& Fedrowitz, J. (1984) In: Methods of enzymatic analysis, Vol. V, 3rd edn. (Bergmeyer, H. U., ed.) pp. 155-159, Verlag Chemie, Weinheim.

16. Yoshioka, H., Oyamada, I. \& Usuku, G. (1987) Anal. Biochem. 166, 172-177. 



\section{Trace Element Analytical Chemistry in Medlicine and Biology • Volume 5}

\section{Proceedings of the Fifth International Workshop Neuherberg, Federal Republic of Germany, April 1988 .,}

Editors Peter Brätter P Peter Schramel

1988. $17 \mathrm{~cm} \times 24 \mathrm{~cm}$. XVII, 666 pages. Numerous illustrations. Hardcover. DM 330,-; approx. US \$188.00 ISBN 3110113406

The subject matter of this volume is oriented towards the state of the art of trace element analytical techniques. Invited experts presented papers reporting on newer aspects of analytical methods, recent developments in preanalytical treatment of biological samples and the combination of analytical methods for speciation analysis. Aluminium and plantinum were elements of special interest. Attention was also paid to the trace element levels in body fluids and tissues as well as to the role of trace elements in metabolic processes and in human nutrition.

\section{Contents (Main Chapters)}

Newer Aspects of Analytical Methods - Preanalytical Steps: Sampling and Sample Treatment - Speciation Analysis - Trace Element Levels (and Reference Data) in Body Fluids and Tissues - Special Elements: Aluminium and Platinum - Nutrition and Food Stuffs - Trace Element Analysis in Diagnosis and Pathological States · Trace Element Metabolism · Subject Index · Author Index

Also available

\section{Trace Element Analytical Chemistry in Medicine and Biology}

Volume 1: 1980, XV， 851 pages. DM 180,-; approx. US \$ 100.00

Volume 2: 1983, XX, 1189 pages. DM 280,-; approx. US \$ 160.00

Volume 3: 1984, XVI, 763 pages. DM 240,-; approx. US \$ 140.00

Volume 4: 1987, XVI, 761 pages. DM 295,-; approx. US \$ 170.00 
17. Bauer, E. A., Eisen, A. Z. \& Jeffrey, J. J. (1972) J. Biol. Chem. 247, 6679-6685.

18. Cooper, T. W., Bauer, E. A. \& Eisen, A. Z. (1983) Collagen Rel. Res. 3, 205-216.

19. Ganrot, P. O. (1966) Clin. Chim. Acta 14, 493 Ganrot, P. O. (1967) Acta Chem. Scand. 21, 602.

20. Kohnert, U., Oberhoff, R., Fedrowitz, J., Bergmann, U., Rauterberg, J. \& Tschesche, H. (1988) In: Proteases Potential role in health and disease (Hörl, W. H. \& Heidland, A., eds.) Advances in Exp. Med. Biol. 240, Plenum, London, New York, $101-114$.

21. Harboe, N. \& Ingild, A. (1973) Scand. J. Immunol. 2, Suppl. 1, 161-164.
22. Ouchterlony, O. (1953) Acta Pathol. Microbiol. Scand. 32 , $231-240$.

23. Tijssen, P. \& Kurstak, E. (1984) Anal. Biochem. 136, 451 457.

24. Porstmann, B., Porstmann, T., Gaede, D., Nugel, E. \& Egger, E. (1981) Clin. Chim. Acta 109, 175-181.

25. Fini, M. E., Plucinska, l. M., Mayer, A. S., Gross, R. H. \& Brinckerhoff, C. E. G. (1987) Biochemistry 26, 61566165.

26. Goldberg, G. I., Wilhelm, S. M., Kronberger, A., Bauer, E. A., Grant, G. A. \& Eisen, A. Z. (1986) J. Biol. Chem. $261,6600-6605$.

Prof. Dr. H. Tschesche

Fakultät für Chemie, Lehrstuhl Biochemie Universität Bielefeld

Universitätsstraße

D-4800 Bielefeld 1 


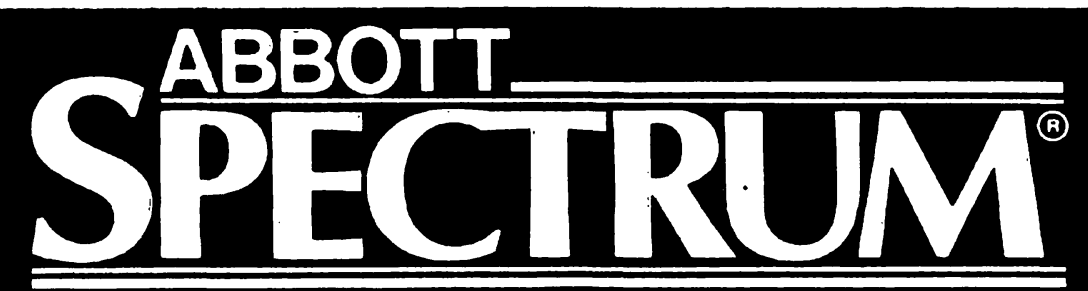

REAGENT BARCODE READER
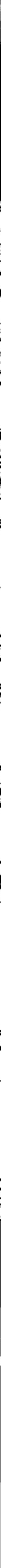

Max-Planck-Ring 2 